\title{
Status of Water Used for Drinking and Irrigation in Kano: A Critical Review on Physicochemical and Heavy Metals Concentration
}

\author{
SAA Shawai ${ }^{*}$, BB Abubakar ${ }^{2}$, MS Nahannu ${ }^{3,4}$ and HS Gaya ${ }^{3}$ \\ ${ }^{1}$ Chemistry Programme, School of Undergraduate Studies, Sa'adatu Rimi College of Education, Nigeria \\ ${ }^{2}$ Department of Biology, School of Science Education, Sa'adatu Rimi College of Education, Nigeria \\ ${ }^{3}$ Department of Chemistry, School of Science Education, Sa'adatu Rimi College of Education, Nigeria \\ ${ }^{4}$ Department of Chemistry, University of East Anglia, United Kingdom
}

*Corresponding author: SAA Shawai, Chemistry Programme, School of Undergraduate Studies, Sa'adatu Rimi College of Education, Nigeria.

To Cite This Article: SAA Shawai. Status of Water Used for Drinking and Irrigation in Kano: A Critical Review on Physicochemical and Heavy Metals Concentration. Am J Biomed Sci \& Res. 2019 - 5(3). AJBSR.MS.ID.000918. DOI: 10.34297/AJBSR.2019.05.000918.

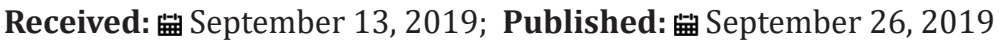

\begin{abstract}
Water is one of the most important natural sources for the sustenance of all living organisms. The importance of water to human's ranges from domestic, industrial and also irrigational activities. The quality of water is affected by human activities as a result of urbanization, population growth, industrial production, climate change and other factors. Several attempts have been made by researchers in order to ascertain the sources of pollution of water in Kano state. This review provides a clear picture of various water analysis carried out by some researchers from different locations in the state. The water status of rivers, dams, ground water and sachet water used in Kano were presented in this paper. Based on the data considered in this paper, revealed that parameters in sachets and ground water consumed in Kano are within the WHO recommended standards for potable water and ensures the suitability of the water for human consumption. Industrial effluents activities contributed immensely in making the river water sources unfit for human and irrigation purposes. This review recommended that, government should sanction any industry that failed to adhere to environmental regulatory policies. Also, government and non-governmental organization should educate the communities on proper disposal of wastes. Phytoremediation should be use for the removal of pollutants from water and soil especially heavy metals.
\end{abstract}

Keywords: Challawa; Heavy metals; Physicochemical; Water

\section{Introduction}

Water is one of the most important and abundant compounds of the ecosystem $[1,2,3]$. It is the most vital element among the natural resources [4,5,6,7], and is critical for the survival of all living organisms including human, food production, and economic development. Also, Saeed and Mahmoud [8] reported that, importance of water in our day-to-day activities makes it necessary for thorough analysis to be conducted. The availability of good quality water is an indispensable feature for preventing diseases and improving quality of life [8-17]. According to Rabiu et al., [15], Abdulazeez [16] and Kalra et al., [17] the quality of water is of vital concern for the mankind since it is directly linked with human welfare or health. The quality of ground water [18], or surface water depends on various chemical constituents and their concentration, which are mostly derived from the geological data of the particular region [19-24]. Usually, water quality is being described by its physical, chemical and biological properties [25-
27]. According to Rahmanian et al., [28] the quality and suitability of water are determined by its taste, odor, colour, as well as the concentration of organic and inorganic matters. According to Nizel and Islam [5] the quality of water is affected by human activities and is declining due to the rise of urbanization, population growth, industrial production, climate change and other factors.

\section{Sources of Pollution}

Pollution is caused when a change in the physical, chemical, or biological condition of the environment harmfully affects the quality of human life, including other animals' lives and plants $[29,30]$. The major causes of water pollution in an environment are as a result of addition of biological or chemical substances, such as land surface washing [31]. Kanase et al., [32], Bhalme and Nagarnaik [33] understand that increase in industrialization, urbanization, agriculture activity and various human activities has increased the 
pollution of surface water and ground water. To Khan et al., [34], increasing anti-environmental human activities and some natural processes the quality of water is decreasing continuously and is posing a great threat to all forms of life including humans. Polluted water is the major cause for the spread of many epidemics and some serious diseases like cholera, tuberculosis, typhoid, diarrhea among others [34]. Contaminants in the water can affect the water quality and consequently the human health. The potential sources of water contamination are geological conditions, industrial and agricultural activities, and water treatment plants as reported by [28]. Duressa et al [35] stated that the problems of contamination of urban water distribution system are diverse.

The major sources of water contaminants are mostly wasting from improper sanitation and agricultural and other activities that make their way to the water distribution networks as reported by $[35,36]$. Industrial wastewater originates from the wet nature of most large industries which require large quantities of water for processing and disposal of wastes. Most industries are therefore, located near water sources. The pollution potential of industrial wastewater is far greater than that of domestic wastewater [37]. Heavy metals are found naturally in the earth [38-40] and become concentrated as a result of human caused activities [41-43] reported that pollution of water with heavy metals is of grave consequence because both terrestrial and aquatic lives may be poisoned; it may cause disease due to the presence of some hazardous substance which may distort the water quality, add odours, and significantly hinder economic activities.

According to Masindi and Muedi [44] heavy metals can be found in traces in water sources and still be very toxic and impose serious health problems to humans and other ecosystems, because the toxicity level of a metal depends on factors such as the organisms which are exposed to it, its nature, its biological role and the period at which the organisms are exposed to the metal.Kano state is located in the northern part of Nigeria, where there is no any large water body or shared border with ocean [45]. Rapid population increase in the study area is as a result of natural increase i.e. birth rate and migration from rural areas into Kano metropolitan and other urban centers in the state from different rural areas within and outside the state which lead to high concentration of people in the Kano metropolitan, which in turn affect water the supply tremendously [46].

\section{Some physico chemical analysis study of polluted water sample in Kano}

Due to the significance of water to living organisms (both plants and animals), numerous studies had been carried out to ascertain the quality of drinking and agricultural water in different places all over the world including Kano state, mainly by determination of heavy metal, physical and chemical among other parameters present due to their impact on human health.

\section{Surface water}

Most of the rivers in the urban areas of the developing countries are the ends of effluents discharged from the industries [47]. Rivers serve as a source of water for human consumption as well as irrigation purposes. Due to the above-mentioned significance, it has become essential for the regular monitoring of the important parameters of the water. The following analysis were reported.

River Challawa: Challawa River is located in Challawa industrial estate $\left(11^{\circ} 45^{\prime} 42 \mathrm{~N}\right.$, longitude $\left.8^{\circ} 46^{\prime} 17 \mathrm{E}\right)$ in Kumbotso local Government area. The River is one of the receiving rivers of effluents from Challawa industrial estate. The industries in the Challawa industrial estate range from tanneries and textile to foods and packaging industries [48-50] conducted research on river Challawa for the purpose of determining the concentration of some physicochemical parameters and heavy metals. The results obtained from the study revealed that, all the physicochemical parameters determined: total solids, total suspended solids, total dissolved solids, temperature, $\mathrm{pH}$, chloride, sulphate, phosphate with exception of dissolved oxygen, biochemical oxygen demand, chemical oxygen demand, and electrical conductivity are within the recommended standard limits for these content in drinking water. The results obtained from this study also indicates the pollution tendencies of the surface waters of river Challawa, attributable to high levels of $\mathrm{Pb}, \mathrm{Cr}$, and $\mathrm{Cd}$ recorded. Akan et al., (2009) in another study on river Challawa investigated the impact of tannery and textile effluents.

The finding of their study reveals that the concentrations of heavy metals in the water and sediment samples were higher than the WHO guideline values for the protection of aquatic life. Also, the concentrations of BOD, COD, and total organic carbon (TOC) were higher than the WHO limits for the protection of fish and other aquatic life. Sarauta and Colleague [51] assessed the presence of PCBs and PAHs in River Challawa and compared the concentrations of the pollutants with the acceptable limit set by Nigerian Standard and other international regulatory agencies. 26 samples of water were considered in the analysis. The result shows that Polychlorinated biphenyls were not detected but polycyclic aromatic hydrocarbons were detected in all the samples analyzed using GCMS. The total concentrations of PAHs in the water samples range between 0.001 to $0.087 \mathrm{mg} / \mathrm{l}$. The results obtained revealed that most of the pollutants present in water were at significantly very high levels especially at Zamawa village situated very close to Challawa industrial estate - the major sources of effluent discharge point, making the drinking water around area is not fit for consumption. The industrial activities had impact on Challawa River basin and its environment as reported.

River Jakara and Minjibir: The work of Akan et al., (2008) on water samples from river Jakara reported the levels of $\mathrm{pH}$, temperature, conductivity, nitrate, nitrite, sulphate, TSS, TDS, phosphate, BOD, COD and DO were higher than the maximum 
permissible limit sets by Federal environmental protection agencies (FEPA). Also reported the concentrations of metals in the wastewater and vegetables samples to be higher than the maximum contaminant limit sets by World Health Organization (WHO). Dike et al., [52] in their study in water samples from river Jakara detected high values of BOD, DO, SS, and chloride and reported the unsuitability of the river for irrigation purposes. In another study, Mustapha et al., [53] analyzed the physicochemical parameters of 27 samples from the riverine network of the upper Jakara River. Parameters like $\mathrm{pH}$, temperature, conductivity, TDS, turbidity, salinity, BOD, COD, ammonia, TSS, SS, Cr, Cd and $\mathrm{Pb}$ were studied and compared with WHO standard. Yahaya et al., [54] carried out a study to determine the physical and chemical parameters of water collected from different points of river Minjibir. The EC, concentration of chloride, sodium, calcium, magnesium, TDS, sodium adsorption rate (SAR), and sulphate recorded in the water samples lies in the impermissible limit sets by WHO and Food and Agricultural Organization (FAO). While the concentrations of carbonate, bicarbonate, nitrate and boron are unsuitable for irrigation purposes as recommended by WHO and FAO.

River Tatsawarki: Bichi and Bello [55] investigated the physicochemical parameters as well as heavy metals concentrations of water samples from Tatsawarki river and concluded that the heavy metal in the water is very high and unfit for any purpose as the metal were found to be higher than the FAO guideline value with exception of $\mathrm{Fe}$ and $\mathrm{Pb}$ which were found to be below the FAO guideline values. Also, the physical and chemical parameters investigated reveals higher levels of TDS, SS, EC, turbidity, magnesium and chlorides than the WHO guideline values in both the irrigation water and the control site. Shawai and Co-authors $[56,57,58]$ evaluated the concentration of some physicochemical parameters, heavy metals and E. coli in the samples collected from the riverine network of River Tatsawarki (Along AKTH/ Dental clinic, Zaria road) and compared with maximum allowable concentration (MAC) of WHO/NSDWQ Standards. Levels of various physicochemical, concentration of some heavy metals and presence of E. coli were determined using standard analytical methods. The results indicated that all the parameters analyzed are within the maximum permissible limits (MPL) recommended, with exception of alkalinity and Total hardness (TH) level at all the sampling station and only IG sampling point shows turbidity level below 5NTU. Also, the presence of E. coli was detected at all the sampling points. The work concluded the suitability of the water for irrigation purposes.

Watari and Tiga Dam: Watari Dam is situated $2 \mathrm{~km}$ from Bagwai town and 8km south west of Bichi, Kano, Nigeria. It has 1,959 hectares surface area with active storage capacity of 92.74 million litres $[59,60]$. The dam is located between latitude $12^{\circ} 9^{\prime} 24^{\prime \prime} \mathrm{N}$ and $8^{\circ} 8^{\prime} 12^{\prime \prime} \mathrm{E}$ with two distinct seasons (wet and dry). The rainy season which last from May to October and the dry season last from November to April. The mean annual temperature is between 16 410Cand the mean annual rainfall ranges from $700-813 \mathrm{~mm}$ [15].
The study of Adamu and Ahmed [59], evaluated the physicochemical composition of Watari Dam for a period of ten months. The result showed monthly variations, where $\mathrm{pH}$, temperature and Electrical conductivity means monthly values ranges between $6.1-8.0,25$ - 31oC, and $61.0-77.0 \mu \mathrm{ohm} / \mathrm{cm}$ respectively. Dissolve oxygen (DO), dissolve solid (DS) and biological oxygen demand (BOD) mean monthly values ranged between 2.5 - 3.9, 33 - 49 and $2.0-$ 4.1 respectively. Suspended solid (SS) and nitrate means values ranges between $2.2-5.8$ and $20.4-27.0$ respectively. Rabiu and co-authors [15] investigated some physicochemical parameters of Watari Dam for a period of ten months.

Four sampling point were considered in this investigation. Mean range of parameters studied were temperature (21.5 - 29.5 $\left.{ }^{\circ} \mathrm{C}\right), \mathrm{pH}(7.3-8.9), \mathrm{DO}(7.4-8.4 \mathrm{mg} / \mathrm{L})$, BOD $(2.6-3.9 \mathrm{mg} / \mathrm{L})$, turbidity $(0.10-0.25 \mathrm{~m})$, electrical conductivity $(156-245 \mu \mathrm{S} /$ $\mathrm{cm})$, TDS (167 - 389mg/L), phosphate (0.5- $2.9 \mathrm{mg} / \mathrm{L})$ and nitrate $(13.5-23.2 \mathrm{mg} / \mathrm{L})$. The result showed some degree of variations between the two seasons in which total dissolved solids, electrical conductivity, turbidity and nitrate recorded significant difference between wet and dry season $(\mathrm{P}<0.05)$ while no significant difference observed in DO, BOD, phosphate, temperature and $\mathrm{pH}$. The phosphate concentration of $13.5-23.2 \mathrm{mg} / \mathrm{L}$ and nitrate concentration of $0.5 \mathrm{mg} / \mathrm{l}$ to $2.89 \mathrm{mg} / \mathrm{L}$ raised concern on accumulation of these elements that can posed threat of pollution to the dam thus indicating anthropogenic influence. Waziri et al., $[61,62]$ investigated the levels and seasonal variations of some physicochemical properties, heavy metals and mineral in water, sediments and fish samples from Tiga dam. Significant differences in heavy metal concentrations were recorded between seasons but, variations within season were statistically insignificant. The result indicated that the Tiga dam water and its aquatic lives are safe for human consumption, irrigation system, domestic and industrial uses.

\section{Tap water}

Water, which is treated by different Municipal bodies, meets all drinking water quality standards at treatment plant and at the point where the water enters the distribution system. Water quality deteriorates in distribution networks and during collection, storage so it becomes obligatory to monitor water quality at each stage [63]. Zakari et al. [64] assessed the changes in the physical and chemical properties of piped-borne water supplied in Kano metropolis from two treatment plants (Challawa and Tamburawa plants), along the distribution lines to the various points of use in Kano metropolis. The research work emphasized on parameters such as $\mathrm{pH}$, alkalinity, conductivity, turbidity, total dissolved solids, total suspended solids, sulphates, chlorides, nitrates, nitrites, sodium, potassium, calcium, magnesium, lead, cadmium, chromium, manganese, iron, nickel, zinc and copper. All the physical and chemical parameters analyzed in the water samples were all within the World Health Organization (WHO) and Standards Organization of Nigeria (SON) limits, hence making piped-borne water in Kano metropolis safe for drinking 
and other purposes. Audu and Idowu [65] analyzed a total of 92 water samples comprising of raw (from plants) and treated (from the plants and taps) were collected for the period of 2 years and analyzed using standard analytical techniques of the parameters analyzed, turbidity and total solids were found to be high in some sampling point, while $\mathrm{pH}$ values were generally acidic.

The highest values of $\mathrm{Fe}, \mathrm{Cu}$ and $\mathrm{Mn}$ were recorded along the older distribution channel of Challawa. The levels of $\mathrm{Pb}$ and $\mathrm{Cr}$ were generally high in both routes which are also observed in the raw water used at the two treatments plants. The results obtained from heavy metal concentrations fell within the maximum allowable limit set by the WHO for portable water except in the cases of $\mathrm{Pb}$ and $\mathrm{Cr}$.

\section{Ground water}

Natural groundwater is usually of good quality, but this can deteriorate due to inadequate source protection and poor resource management [66]. It's contamination may be due to improper dwelling of well and waste disposal [67]. Dohare et al., [68] reported that groundwater is used for domestic and industrial water supply and also for irrigation purposes in all over the world. Bernard and Ayeni [69] ascertained the quality of ground water in Bichi local government area and compared the results with the accepted limits of World Health Organization (WHO) and Standard Organization of Nigeria (SON). The samples taken from twenty different locations revealed that the study area has a mean of Turbidity $2.0 \mathrm{NTU}$, Colour 2.5 TCU, Temp. $25^{\circ} \mathrm{C}, \mathrm{pH}$ 6.8, Total Alkalinity $85.0 \mathrm{mg} / \mathrm{l}$, Total Hardness $71.83 \mathrm{mg} / \mathrm{l}$, and others are: Calcium $25.24 \mathrm{mg} / \mathrm{l}$, Magnesium $2.19 \mathrm{mg} / \mathrm{l}$, Iron 0.05 , Chloride $7.89 \mathrm{mg} / \mathrm{l}$, Nitrate 0.79 $\mathrm{mg} / \mathrm{l}$, Total dissolved solid $81.0 \mathrm{mg} / \mathrm{l}$, and Conductivity $135 \mathrm{~S} / \mathrm{cm}$. Based on the results obtained, the ground water satisfied the safety limit for various purposes including; domestic, agricultural, and industrial. The study of Adamu et al., [70] investigated the quality of groundwater for safe drinking, by testing parameters like $\mathrm{pH}$, Electrical conductivity (EC) and Ionic concentration of Calcium $(\mathrm{Ca})$, Magnesium $(\mathrm{Mg})$, Iron $(\mathrm{Fe})$, Chlorine $(\mathrm{Cl})$, Nitrate $\left(\mathrm{NO}_{3}\right)$, Ammonium Nitrate (NH3N), Sulphate (II)oxide (SO42-), Silicon oxide (SiO2), Fluoride (F-), Carbon dioxide (CO2) and TDS from various Precambrian Basement Complex rocks in Kano State.

The parameters analyzed, shows that the groundwater from the study area is fit for human consumption. Sa'eed and Amira [71] assessed some physicochemical parameters of borehole water used for drinking and domestic purposes in Nasarawa Local government Area. pH, Alkalinity, Conductivity, Total dissolved solids (TDS), Total hardness, Permanent hardness, temporary hardness were among the parameters analyzed. The results indicated that $\mathrm{pH}$, conductivity and total dissolved solids were within the acceptable range recommended by World Health Organization. (WHO), while Alkalinity, Total hardness, Permanent hardness, Temporary hardness, Calcium hardness and Magnesium hardness were all above the safe limit recommended by WHO. Saeed and Mahmoud
[8] evaluated the physical and chemical parameters as well as heavy metals concentrations of drinking water used in Fagge local government area in Kano. The results indicated that, all the physicochemical and heavy metals are within the acceptable limits set by WHO except for pH level at Weather head and lead level in Kwarin gogau sampling sites respectively.

A research was undertaken by Nahannu et al., [72]; Shawai et al., [73] in Gezawa, Nigeria to have an idea of the extent of ground water pollution due to contamination with industrial effluents as well as sewage wastes. Shawai et al., [60] conducted water quality assessment in Unguwa Uku, Kano metropolitan Nigeria in October 2016 and reported that, agricultural activities as well as effluents from domestic and abattoir are the major causes of water pollution within the study area. The research work carried out by Bataiya et al., [74] to investigate the contamination level of groundwater by determination of physical and chemical properties, revealed that the groundwater quality is deteriorated due to higher concentration of EC TDS and hardness as compared to WHO standards. As the result indicated all the parameters are within the recommended levels set by WHO and NSDWQ except for conductivities at all the samples site, and magnesium at $\mathrm{D}_{1}, \mathrm{D}_{2}$, and $\mathrm{D}_{3}$. The work of Hassan and co-workers [75] analyzed $\mathrm{pH}$, temperature, TDS, TSS, SS, EC, Alkalinity, $\mathrm{Mg}^{2+}, \mathrm{Ca}^{2+}$, colour, free $\mathrm{CO}_{2}$, turbidity, $\mathrm{TH}$ and Chloride. The results indicated that all the parameters analyzed are within the permissible limits recommended by World Health Organization (WHO) and Nigerian Standard for Drinking Water Quality (NSDWQ) with exception of turbidity level at YS sampling station, Mg2+ concentration at DS and YS sampling point and total hardness from sampling point DS.

Physicochemical and bacteriological analyses were carried out on well water samples from eight selected locations within the industrial area of Kano Metropolis including Bompai, Sharada, Challawa and Jaba [19]. The physicochemical parameters monitored includes $\mathrm{pH}$, electrical conductivity, TDS, DO, BOD, Turbidity, chloride, nitrate, phosphate, zinc, iron, lead, manganese and chromium. The result revealed concluded that seven out of the eight (8) wells assessed were not fit for consumption. Shawai et al., [56] determine the physicochemical parameters of water samples collected from Sa'adatu Rimi College of Education, Kumbotso Kano and compared with the standards recommended by WHO and NSDWQ. Four samples were collected from different locations within the college premises for the analysis. The analyzed parameters are within the permissible limits recommended by WHO and NSDWQ with exception of turbidity level at A sampling station, $\mathrm{pH}$ concentration at $\mathrm{B}, \mathrm{C}$, and $\mathrm{D}$ sampling point and nitrite concentrations at $\mathrm{C}$ and $\mathrm{D}$ sampling point. The results also showed that, the concentration of total hardness was slightly above. The work suggested that, levels of microbial contaminant, inorganic constituents and other parameters not considered in the research should be assess in future study. 


\section{Sachet Water}

Water can be described as potable, when it complies with certain physical, chemical and microbiological standards, which are designed to ensure that the water is potable and safe for drinking [76]. Sachet/packaged/potable water is the water that is free from disease producing microorganisms and chemical substances that are dangerous to health [77-85]. Packaged water is raw water purified to remove physical, chemical and microbial contaminants and packaged into labeled containers [86,87]. The production and sell of sachet/package water or pure water is one of the common businesses in Kano Nigeria, so the need to assess the status become necessary. In Kano, sachet water is main water used for drinking especially in metropolitan area. Analysis were carried out to assess the quality of this water, including the following:

Uwah and co-workers [88] concluded that the physicochemical and bacteriological parameters in sachets water consumed in Kano metropolis conformed to the WHO recommended standards for potable water and that the consumption of the sachets water may not pose health hazards to the consumers at the time of the study. 25 brands of sachet water packaged within Kano metropolis was evaluated by [89]. Concentrations of $\mathrm{Pb}, \mathrm{Fe}, \mathrm{Zn}$ and $\mathrm{Cu}$ were determined using atomic absorption spectrophotometer (AAS). Conductivity, $\mathrm{pH}$, Total dissolved solids and total hardness were determined using suitable methods of analysis. The concentrations of the metals, conductivity, TDS and total hardness were below the allowable limits set by standard organization of Nigeria (SON) and WHO. However, pH concentration was found to be high in some samples analyzed. Sheshe and Magashi [90] analysed fifty (50) brands of sachet water produced from borehole and tap water in five local government areas of Kano metropolitan. Chemical parameters such as conductivity, total hardness, nitrate and nitrite, total dissolved solids, fluoride, and heavy metals such as Manganese (Mn), Arsenic (As), Zinc (Zn), Copper (Cu), and Lead $(\mathrm{Pb})$ conformed to the requirements of WHO and NIS standards.

The findings revealed that the physicochemical parameters tested in all the sachet water samples were within the permissible limits stipulated by the drinking water standards, hence on this basis the water is considered fit for drinking.

\section{Conclusion}

The effects of water pollution are not only devastating to people but also to animals, plants, and soil. Polluted water is unsuitable for drinking, recreation, agriculture, and industrial activities. The present review paper undertaken to account to bring an acute awareness among the people about the quality of water in Kano state. Based on the previous research, it can be concluded that the parameters in sachets and ground water consumed in Kano are within the WHO recommended standards for potable water and ensures the suitability of the water for human consumption. In case of river and dams' water, industrial effluents contributed immensely in making the river water sources unfit for human and irrigation purposes.

\section{Recommendations}

The following recommendations were made:

1) The agencies concerned such as FME, KSME, NAFDAC, NASREA, SON among others, should strengthen their legislation against indiscriminate and improper waste disposal along waterways.

2) Hand dug wells and boreholes should be drilled some meters far away from any source of contaminations or pollution.

3) Government should sanction any industry that failed to adhere to environmental regulatory policies.

4) Also, government and non-governmental organization should educate the communities on proper disposal of wastes.

5) Phytoremediation should be use for the removal of pollutants from water and soil especially heavy metals.

6) There is need for regular water quality monitoring which should include trace metal levels, nutrients and microbiological analysis.

\section{References}

1. Sharma V, Walia YK (2016) Water quality assessment of Gobind Sagar Lake during rainy season in Himachal Pradesh, India. Biological Forum 8(1): 559-564.

2. Sagar SS, Chavan RP, Patil CL, Shinde DN, Kekane SS (2015) Physico-chemical parameters for testing of water-A review. International Journal of Chemical Studies 3(4): 24-28.

3. Basavaraja Simpi, Hiremath SM, Murthy KNS, Chandrashekarappa KN, Anil NP, et al. (2011) Analysis of Water Quality Using Physico-Chemical Parameters Hosahalli Tank in Shimoga District, Karnataka, India. Global Journal of Science Frontier Research 11(3): 31-34.

4. Keerthika D, Gokulpriyan K, Harini I, Karthikeyan V (2019) Studies on Physicochemical Analysis of Water from Different Sources. International Journal of Environment Agriculture and Biotechnology 4(2): 310-313.

5. Joshua Nizel H, Nazrul Islam M (2015) Water Pollution and its Impact on the Human Health. Journal of Environment and Human 2(1): 36-46.

6. Shukla D, Bhadresha K, Jain NK, Modi HA (2013) Physicochemical Analysis of Water from Various Sources and Their Comparative Studies. IOSR Journal of Environmental Science, Toxicology and Food Technology (IOSR-JESTFT) 5(3): 89-92.

7. Nabila B, Ahmed B, Kacem M (2014) An assessment of the physico-chemical parameters of Oran sebkha basin. Applied Water Science 4(4): 351-356.

8. Saeed MD, Mahmoud AM (2014) Determination of some Physicochemical Parameters and some Heavy Metals in Boreholes from Fagge LGA of Kano Metropolis Kano State -Nigeria. World Journal of Analytical Chemistry 2(2): 42-46.

9. Shaka A, Ebhoaye J, Osuide M (2018) Investigation of Some Pollution Indices of Underground Water Reservoirs in Ekpoma, Esan West Local Government Area of Edo State, Nigeria. SAU Science-Tech Journal 3(1): 122-125.

10. Varsha Nigam, Neelam Behl, MC Kanchan (2013) Physico-chemical parameters for testing of water-a review. International Journal of Pharmacy and Biological Sciences 3(3): 523-527. 
11. Patil PN, Sawant DV, Deshmukh RN (2012) Physico-chemical parameters for testing of water-A review. International Journal of Environmental Sciences 3(3): 1194-1207.

12. Dinrifo RR, Babatunde SOE, Bankole, Demu QA (2010) Physicochemical Properties of Rainwater Collected from Some Industrial Areas of Lagos State. Nigeria European Journal of Scientific Research 41: 383-390.

13. Adefemi SO, Awokunmi EE (2010) Determination of physico-chemical parameters and heavy metals in water samples from Itaogbolu area of Ondo-State, Nigeria. African Journal of Environmental Science and Technology 4(3): 145-148.

14. Oluduro AO, Adewoye BI (2007) Efficiency of moringa Oleifera Sead extract on the microflora of surface and ground water. J Plant Sci 6: 438453.

15. Rabiu HD, Umar LM, Sulaiman I, Madina M, Abubakar AI (2018) Assessment of the water quality of Watari dam, Kano state using selected physicochemical parameters. International Journal of Advanced Academic Research Sciences, Technology and Engineering 4(5): 61-77.

16. Abdulazeez MT (2015) Limnological studies of Karidna Reservoir, in Igabi Local Government area of Kaduna State, Nigeria. MSc Thesis Ahmadu Bello University, Zaria p. 68.

17. Kalra N, Rajesh Kumar SS, Yadav, Singh RT (2012) Physico-chemica analysis of ground water taken from five blocks (Udwantnagar, Tarari, Charpokhar, Piro, Sahar) of southern Bhojpur (Bihar). Journal of Chemical and Pharmaceutical Research 4(3): 1827-1832.

18. Chindo IY, Karu E, Ziyok I, Amanki ED (2013) Physicochemical Analysis of Groundwater of Selected Areas of Dass and Ganjuwa local Government Areas, Bauchi State Nigeria. World Journal of Analytical Chemistry 1(4): 73-79.

19. Yahaya S, Janet TS, Kawo AH (2017) Bacteriological and Physicochemical Assessment of Drinking Water from wells located in the Industrial Areas of Kano Metropolis. UJMR 2(2): 233-236.

20. Kondulkar SR, Khandelwal MG, Chaudhari UE, Wanjari AK, Markam GM (2015) Physico-Chemical Analysis of Ground Water Affected by Ganapati Visarjan. International Journal of Advanced Research in Chemical Science 2(11): 8-10.

21. Jalali M (2005) Major ion chemistry of groundwater in the Bahar area, Hamadan, western Iran. Environmental Geology 47(6): 763-772.

22. Aftab Begum SY, Noorjahan CM, Dawood Sharif S (2005) Physico-chemical and fungal analysis of a fertilizer factory effluent. Nature Environment and Pollution Technology 4(4): 529-531.

23. Chavan RP, Lokhande RS, Rajput SI (2005) Monitoring of organic pollutants in Thane creek water. Nature Environment and Pollution Technology 4(4): 633-636.

24. Gnana Rani DF, Arunkumar K, Sivakumar SR (2005) Physio-chemical analysis of wastewater from cement units. Journal of Industrial Pollution Control 21(2): 371-374.

25. Sharma N, Walia YK (2017) Water Quality Investigation by Physicochemical Parameters of Satluj River (Himachal Pradesh, India). Current World Environment 12(1): 174-180.

26. Sharma RK, Soni DK, Agrawal N (2012) A study on physico-chemical parameters of Dah lake water, District-Ballia (UP), India. Journal of Applied and Natural Science 4(2): 237-240.

27. Vandana Sharma, Yogesh Kumar Walia, Aditya Kumar (2015) Assessment of Physico Chemical Parameters for Analysing Water. A Review Biol Chem Chron 2(1): 25-33.

28. N Rahmanian, Siti Hajar Bt Ali M, Homayoonfard, NJ Ali, M Rehan, et al (2015) Analysis of Physiochemical Parameters to Evaluate the Drinking Water Quality in the State of Perak, Malaysia. Journal of Chemistry 2015: $1-10$.

29. Aliyu TH, Balogun OS, Namani CS, Olatinwo LK, Aliyu AS (2017) Assessment of the presence of metals and quality of water used for irrigation in Kwara State, Nigeria. Pollution 3(3): 461-470.
30. Okoye PAC, Enemuoh RE, Ogunjiofor JC (2002) Traces of heavy metals in marine crabs. Journal of Chemical Society of Nigeria 27(1): 76-77.

31. S Devi, R Premkumar (2012) Physicochemical Analysis of Groundwater samples near Industrial Area, Cuddalore District, Tamilnadu, India. International Journal of Chem Tech Research 4(1): 29-34.

32. Kanase DG, Shaikh SA, Jagadale PN (2016) Physicochemical Analysis of Drinking Water Samples of Different Places in Kadegaon Tahsil, Maharashtra (India). Advances in Applied Science Research 7(6): 41-44.

33. Bhalme SP, Nagarnaik PB (2012) Analysis of drinking water of different places-A review. International Journal of Engineering Research 2(3): 3155-3158.

34. Khan MY, Shabeer M, Raja IA, Wani NA (2012) Physico-Chemical Analysis of River Jhelum (Kashmir). Global Journal of Science Frontier Research Interdisciplinary 12(1): 1-4.

35. Duressa G, Assefa F, Jida M (2019) Assessment of Bacteriological and Physicochemical Quality of Drinking Water from Source to Household Tap Connection in Nekemte, Oromia, Ethiopia. Journal of Environmental and Public Health 2019: 7.

36. Tabor M, Kibret M, Abera B (2011) Bacteriological and physic-chemical quality of drinking water and hygiene-sanitation practices of the consumers in Bahir Dar city, Ethiopia. Ethiopian Journal of Health Sciences 21(1): 19-26

37. Dan'azumi S, Bichi MH (2010) Industrial Pollution and Implication on Source of Water Supply in Kano, Nigeria. International Journal of Engineering and Technology IJET-IJENS 10(1): 76-81.

38. Adeola OA (2017) Review on heavy metals contamination in the environment. European Journal of Earth and Environment 4(1): 1-6.

39. Rajeswari TR, sailaja N (2014) Impact of heavy metals on environmental pollution. Journal of Chemical and Pharmaceutical Sciences 3: 175-181.

40. Singh R, Gautam N, Mishra A, Gupta R (2011) Heavy metals and living systems: An overview. Indian, J Pharmacol 43(3): 246-253.

41. Thomas S, Mohaideen AJ (2014) Analysis of Heavy Metals in fish, water and sediment from Bay of Bengal. International Journal of Engineering Science Invention 3(8): 41-46.

42. Uzairu OJ, Okunola RJ, Wakawa, SG Adewusi (2014) Bioavailability Studies of Metals in Surface Water of River Challawa, Nigeria. Journal of Applied Chemistry 2014: 1-9.

43. C Asonye, NP Okolie, EE Okenwa, UG Iwuanyanwu (2007) Some physico-chemical characteristics and heavy metal profiles of Nigerian rivers, streams and waterways. African Journal of Biotechnology 6(5): 617-624.

44. Masindi V, Muedi KL (2018) Environmental Contamination by Heavy Metals, Heavy Metals. Hosam El-Din M Saleh, Refaat F Aglan, Intech Open

45. Bello NI, Tuna F (2014) Evaluation of potable water demand and supply in Kano state, Nigeria. International Journal of Scientific Knowledge 4(6): 35-42.

46. Bello NI, Abdullahi IK (2014) Water supply situations in Kano metropolitan prospects and challenges. International Journal of Research in Earth \& Environmental Sciences 1(4): 25-32.

47. Bajpai R (2012) Comparative Analysis of Physicochemical Parameters of Hasdeo River Barrage and Arpa River Water Samples of Bilaspur Region. International Journal of Scientific and Research Publications 2(9): 1-5.

48. Abdullahi U, Audu AA, Kalimullah, Shuaibu L (2016) Phytoremediation of Contaminated Soils from Challawa Industrial Estate, Kano-Nigeria. Science Journal of Analytical Chemistry 4(5): 59-65.

49. Wakawa RJ, Uzairu A, Kagbu JA, Balarabe ML (2008) Impacts assessment of effluent discharge on physicochemical parameters and some heavy metals concentrations in surface water of river Challawa Kano, Nigeria. African Journal of Pure and Applied Chemistry 2(10): 100-106.

50. Mustapha MK (2008) Assessment of the water quality of Oyun reservoir 
Offa, Nigeria using selected physicochemical parameters. Turkish Journal of Fisheries and Aquatic Sciences 8: 309-319.

51. Sarauta A, Sabo A, Abdulhamed IA, Yusuf YO (2015) Assessment of persistent organic pollutants in water samples from River Challawa in Kano, Nigeria. World Journal of Environmental Research 5(2): 159-177.

52. Dike NI, Ezealor AU, Oniye SJ, Ajibola VO (2013) Pollution studies of river Jakara in Kano Nigeria, using selected physicochemical parameters. International Journal of Research in Environmental Science and Technology 3(4): 122-129.

53. Mustapha A, et al. (2013) River water quality assessment using environmentric techniques: Case study of Jakara river basin. Environmental Science Pollution and Research.

54. Yahaya MN, Umar FG, Jibrin DM, Idris UD (2015) Assessment of water quality of river Minjibir for irrigation purposes in Kano state, Nigeria. Nigerian Journal of Agriculture, Food and Environment 11(3).

55. Bichi MH, Bello UF (2013) Heavy metal pollution in surface and ground waters used for irrigation along river Tatsawarki in the Kano state, Nigeria. IOSR Journal of Engineering 3(8): 1-9.

56. Shawai SAA, Musa RK, Bilkisu BA, Muazu J (2018) Evaluation of physicochemical characteristics of groundwater from selected areas in Unguwa Uku, Kano metropolitan, northwestern Nigeria. International Journal of Biomedical Materials Research 6(1): 8-12.

57. Shawai SAA, Nahannu MS, Abdulkadir S, Minjibir SA (2018) Evaluation of Physicochemical Parameters and Some Heavy Metals in Water Samples Used for Irrigation Purpose along River Tatsawarki In Tarauni LGA Kano. International Journal of Scientific Research in Chemical Sciences 5(6): 1-4.

58. Shawai SAA, Nahannu MS, Mukhtar HI, Isma'il IM (2019) Assessment of Groundwater Samples from Sa'adatu Rimi College of Education, Kumbotso, Kano. Journal of Medicinal and Chemical Sciences 3(2): 96-100.

59. Adamu R, Ahmed AW (2017) Physicochemical Assessment on Quality of Watari Dam Water, Kano State, Nigeria. International Journal of Innovative Research and Advanced Studies (IJIRAS) 4(11): 225-228.

60. Adamu GA, Sallau MS, Idris SO, Agbaji EB (2014) Seasonal variations of some physico-chemical parameters of Watari reservoir, treated and potable water, in Kano state Nigeria. International Journal of Technical Research and Applications 2(7).

61. Waziri M, Baba NM, Audu AA, Zakaria ZI (2015) Seasonal variations in physicochemical properties of water, sediments and fish of Tiga dam Kano-Nigeria. Nigerian Journal of Chemical Research 20: 39-45.

62. Suleiman FB, Audu AA (2014) Analysis of Water from some Dams in Katsina State, Nigeria. IOSR Journal of Applied Chemistry (IOSR-JAC) 7(1) 01-09.

63. Somani PD, Ray S, Singh S (2014) Assessment of water quality. International Journal of Scientific and Engineering Research 5(12): 67-70.

64. Zakari A, Ikudayisi VA, Giwa SI (2014) Quality Assessment of the Changes in the Physico-Chemical Parameters in Pipe-Borne Water Supplied in Kano Metropolis, Nigeria, IOSR Journal of Applied Chemistry (IOSR-JAC) 7(11): 74-81

65. Audu A, Idowu A (2015) The Effect of the Challawa Industrial Estate on the Physicochemical Properties and Heavy Metal Levels of Portable Water Supply in Kano Metropolis, Nigeria. Journal of Geoscience and Environment Protection 3: 17-22.

66. Allamin IA, Borkoma MB, Joshua R, Machina IB (2015) Physicochemical and Bacteriological Analysis of Well Water in Kaduna Metropolis, Kaduna State. American Journal of Pharmacy and Pharmaceutical Sciences 2(1): 1-8.

67. Allamin IA, Borkoma MB, Joshua R, Machina IB (2015) Physicochemical and Bacteriological Analysis of Well Water in Kaduna Metropolis, Kaduna State. Open Access Library Journal 2: e1597.
68. Dohare D, Deshpande S, Kotiya A (2014) Analysis of Ground Water Quality Parameters: A Review. Research Journal of Engineering Sciences 3(5): 26-31.

69. Bernard E, Ayeni N (2012) Physicochemical Analysis of Groundwater Samples of Bichi Local Government Area of Kano State of Nigeria. World Environment 2(6): 116-119.

70. Adamu GK, Tukur R, Kankara AI (2013) Ground Water Quality Assessment in the Basement Complex Areas of Kano State Nigeria. American Journal of Engineering Research 2(7): 171-175.

71. Sa'eed MD, Amira AH (2013) Physicochemical analysis of ground water samples from Nasarawa LGA, Kano State-Nigeria. Journal of Chemical and Pharmaceutical Research 5(8): 162-173.

72. Nahannu MS, Shawai SAA, Ibrahim MS, Muhammad UL, Yahaya AS, et al. (2017) Physicochemical analysis of groundwater samples in Gezawa local government area of Kano state of Nigeria. Advances in Bioscience and Bioengineering 5(6): 92-95.

73. Shawai SAA, Nahannu MS, Mukhtar HI, Idris A, Abdullahi II (2017) Assessment of heavy metals concentration in groundwater from various locations in Gezawa local government area of Kano state. Advances in materials 6(5): 73-76

74. Bataiya AG, Habiba M, Ahmad SI, Muazu J (2017) Analysis of Water Quality Using Physicochemical Parameters of Boreholes Water Taken from areas around Dala Hills, Northwestern Nigeria. American Journal of Water Science and Engineering 3(6): 80-83.

75. Hassan AS, Abubakar IB, Musa A, Limanchi MT (2017) Water Quality Investigation by Physicochemical Parameters of Drinking Water of Selected Areas of Kureken Sani, Kumbotso Local Government Area of Kano. International Journal of Mineral Processing and Extractive Metallurgy 2(5): 83-88.

76. Amita Yadav, GS Gupta (2017) Evaluation of Physico-Chemical and Bacteriological Parameters in Drinking Water of Chitrakoot Nagar Panchayat Area (MP) India. International Journal for Research in Applied Science \& Engineering Technology 5(X): 2052-2058.

77. Ikhumetse AA (2019) Bioremediation Efficiency of Saccharomyces cerevisiae on Cadmium and Lead from Groundwater Obtained from Mining Community. Advance in Environmental Waste Management \& Recycling 2(1): 1-9.

78. Asiya A, Ali M (2017) Biological Control of Water Pollution at Challawa Industrial Area Kumbotso Local Government, Kano using Moringa oleifera Seed Extract. Greener Journal of Biological Sciences 7(7): 63-68.

79. Choudhury SS, Keot A, Das H, Das M, Baishya C, et al. (2016) Preliminary Physicochemical and Microbiological Analysis of Bahini River Water of Guwahati, Assam, India. International Journal of Current Microbiology and Applied Sciences 5(2): 684-692.

80. Salih NY, NA Al-Azzawi N (2016) Human Health Risk Assessment of Trihalomethane through Multipath way Exposure from Drinking Water of Baghdad. Journal of International Environmental Application and Science, Iraq 11(3): 294-302.

81. Latha M, Mohan MR (2014) Evaluation of bacteriological water quality, Bangalore- in view of public health. International Journal of Chemical Studies 2(1): 12-18.

82. Udiba UU, Bashir Inuwa, Akpan Nsikak S, Olaoye Sikemi, Idio Uduakobong I, Odeke Everlyn H, Ugoji Victoria, Anyahara Stella, Agboun TDT (2013) Impact of mining activities on ground water quality status, Dareta Village, Zamfara, Nigeria. Archives of Applied Science Research 5(1): 151-158.

83. United Nations Children Education Fund (UNICEF) (2010) Supply Division, Technical bulletin 6: 10 .

84. Shittu OB, Olaitan JO, Amusa TS (2008) Physico-Chemical and Bacteriological Analyses of Water Used for Drinking and Swimming Purposes in Abeokuta, Nigeria. African Journal of Biomedical Research 11: 285-290. 
85. Lamikaran A (1999) Essential Microbiology for students and Practitioners of Pharmacy, Medicine and Microbiology. 2nd ed. Amkra books, 406p. Lee

86. Abubakar A, Babagana M, Gashua MM (2016) Assessment of water quality of some table water companies in Kano metropolis, Nigeria. Scholars Academic Journal of Biosciences 4(3B): 233-236.

87. Alhassan AJ, Imam AA, Yakasai HM (2008) Quality assessment of sachet water packaged around Kano metropolis Nigeria. Bayero Journal of Pure and Applied Sciences 1(1): 83-87.
88. Uwah EI, Busari WR, Sayi A (2014) Physicochemical and Bacteriological Analyses of Sachets Water Samples in Kano Metropolis, Nigeria. IOSR Journal of Applied Chemistry (IOSR-JAC) 6(6): 52-56.

89. Uduma AU, Maria B, Uduma (2014) Physicochemical Analysis of the Quality of Sachet Water Consumed in Kano Metropolis. American Journal of Environment, Energy and Power Research 2(1): 1-10.

90. Sheshe MU, Magashi AM (2014) Assessment of physicochemical quality of sachet water produced in selected local government areas of Kano metropolis, Kano state - Nigeria. Bajopas 7: 2. 